\title{
Leaders
}

\section{Proliferation markers in tumours: interpretation and clinical value}

\author{
Paul J van Diest, Gerard Brugal, Jan P A Baak
}

\section{Department of Pathology, Free University Hospital, Amsterdam, The Netherlands P J van Diest J P A Baak}

\section{Institut Albert Bonniot, Université Joseph Fourier, Grenoble, France G Brugal \\ Correspondence to: Dr Paul J van Diest, Department of Pathology, University Hospital Vrije Universiteit, PO Box 7057 1007 MB Amsterdam, The Netherlands; email: pi.vandiest@azvu.nl}

Accepted for publication 13 May 1998
Proliferation is one of the most fundamental of biological processes because of its role in growth and in the maintenance of tissue homeostasis. In tumours especially, proliferation has traditionally received much attention. On the one hand, proliferation has been studied as an important cell biological mechanism in oncogenesis, often using rather laborious methods applicable only in experimental conditions, such as tritiated thymidine incorporation. On the other hand, assessment of proliferation has become popular in histopathology as a means of predicting the behaviour of tumours - that is, their likelihood of local recurrence, their metastatic potential, and the growth of metastases, and thereby the disease-free survival and survival to death. This is owing to the fact that different methods have become available to assess certain properties of cellular proliferation that are readily available in daily histopathological practice. This has led to vast numbers of studies on the value of these methods for the diagnosis of different kinds of tumours and clinical decision making. In this review we aim to provide an overview of methods currently available for assessment of proliferation, and to discuss critically their cell biological framework, their methodology, and some of the most important applications of these methods. First, however, a description of the cell cycle is necessary, to provide the context within which the different methods of assessing proliferation will be interpreted.

\section{The cell cycle}

Several phases of cellular proliferation can be recognised. From the resting $\left(\mathrm{G}_{0}\right)$ phase of highly variable duration, in which cells do not take part in the cell cycle, they eventually join the cycling population after suitable stimuli and enter the first gap $\left(G_{1}\right)$ phase, which has a variable duration. In the $G_{1}$ phase, the cell prepares for the synthesis or $S$ phase, in which DNA synthesis and doubling of the genome occur; this usually takes between seven and 12 hours. The $S$ phase is followed by a period of apparent inactivity known as the second gap $\left(G_{2}\right)$ phase (usually one to six hours), in which the cell prepares for further separation of chromatids during the mitotic (M) phase, which takes generally between one and two hours. After the $M$ phase, each daughter cell may enter $G_{0}$ phase or move on to the $G_{1}$ phase of a cell cycle. The interphase-which is comprised of the $G_{1}, S$, and $G_{2}$ phases-forms the largest part of the cell cycle, but cells in these phases cannot be morphologically recognised. Cells in the mitotic phase can be identified because of the typical appearance of the chromosome sets during the different subphases of the $M$ phase. This has been the basis for mitosis counting on light microscopy - the oldest way of assessing proliferation. Several other methods have become available to assess proliferation, based on other cell cycle fractions or on cell cycle phenomena besides mitosis. These include incorporation techniques, per cent $S$ phase cell determination by DNA cytometry (\%Sphase), immunohistochemistry of proliferation associated antigens, and nucleolar organiser regions. All these methods have their advantages and disadvantages from a cell biological or practical point of view, and these will be discussed later. Discussion of cell cycle regulation is beyond the scope of this review.

Proliferative activity and tumour growth Growth is the overall increase in cell number, so is the net result of cell gain by proliferative activity and cell loss by apoptosis or necrosis. Proliferative activity results from cell cycling. The mechanisms responsible for proliferative activity (P) are the speed of the cell cycle, which is inversely proportional to the generation time ( $\mathrm{T}$ ) on the one hand, and to the proportion of cells committed to the cycle-the growth fraction $(\mathrm{G})$ - on the other. The mathematical relation between proliferative activity, growth fraction, and generation time is $\mathrm{P}=$ G/T. A high proliferative activity can therefore be the result of either a high growth fraction or a short generation time, or both. Roughly, a proliferative activity of 0.01 cell/cell of the population/hour is obtained with a $\mathrm{T}$ of 100 hours and a growth fraction of $10 \%$, as well as with a $\mathrm{T}$ of 500 hours and a growth fraction of $50 \%$. Clearly neither of the techniques described below, defining growth fraction or generation time alone, can accurately describe proliferative activity.

The doubling time ( $\mathrm{Td}$ ) of a tumour in case of no cell loss is defined by $\mathrm{Td}=\mathrm{T}(\mathrm{log}$ $2 / \log (G+1))$. A short doubling time therefore results from either a short cycle time or a high growth fraction, or both. Several methods are available to assess growth fraction as described 
below, but assessment of cell cycle time is much more complicated.

\section{Markers of proliferation}

INCORPORATION TECHNIQUES

Incorporation techniques are based on in vivo or in vitro incorporation of labelled nucleotide analogues, such as tritiated thymidine or bromodeoxyuridine (BrdU). Incorporated radioactive thymidine can be visualised by autoradiography, and incorporated BrdU can be revealed by immunohistochemistry. These incorporation methods are popular in biology and can be regarded as a gold standard marker of $S$ phase cells. In a clinical setting, they are less useful. In vivo injection with radioactive thymidine is not popular, handling radioactive active material is cumbersome, and the autoradiographic development can take up to two weeks. It is also possible to incorporate tumour material in vitro with tritiated thymidine as for BrdU, but this does not take away the other disadvantages. By pulse labelling, an estimate can also be obtained on the number of cells entering $S$ phase during a certain period of time, and thereby of cell cycle time. ${ }^{1}$ It is not easy to count positively labelled cells reliably - as demonstrated by Meyer and McDivitt, who found coefficients of variation up to $55 \%$ on repeated counts. ${ }^{2}$ In general, few studies have been devoted to optimising the counting of cells labelled with tritiated thymidine.

\section{MITOTIC INDEX}

Counting of mitotic figures is the oldest way of assessing proliferation. Ever since the introduction of microscopes made the recognition of mitotic figures possible, counting mitotic figures has been applied as a diagnostic tool, especially in tumour pathology. Even though many other ways of assessing proliferation have become available, the ease with which mitoses can be recognised without special equipment apart from a decent microscope and a well stained H\&E slide has led to the increasing popularity of this way of counting of mitotic figures up to the present.

Strict morphological criteria should be applied for the recognition of mitotic figures. ${ }^{3-6}$ Mitoses can be defined as dark clots of chromosomes which can often be recognised by the presence of hairy extensions when focusing up and down, while the nuclear envelope is absent and the cytoplasm is basophilic rather than eosinophilic. These chromosomal clots can have the configuration of the metaphase, anaphase, or telophase.

Several approaches may be followed when counting mitotic figures. Most often, the number of mitoses is expressed as the total number in a defined number (for example, 10) high power fields (HPF). The exact area of the HPF must, however, be defined to be able to compare results from different studies, since the area of field of vision can vary considerably between different objectives. Unfortunately, most workers have failed to do so in the past, which has led to much criticism. Therefore, some use the number of mitotic figures per unit area (for example, $2 \mathrm{~mm}^{2}$ ). It may also be use- ful to correct for the actual content of tumour cells within the slide by expressing the number of mitoses per a certain number of tumour cells (for example, 1000), which yields the mitotic rate, or to correct the number of mitotic figures for the area percentage of epithelium, which yields the mitoses per volume (MV) index. ${ }^{7}$ These methods are potentially time consuming, but stereological sampling approaches are quite useful to keep the extra time spent within acceptable limits. $^{89}$

The reproducibility of mitosis counting has been questioned. Indeed, when standardised methodology is not used quite variable results may be obtained on the same material by different observers, ${ }^{10}$ but after thorough training and following a strict protocol, excellent inter-reproducibility results have been obtained. ${ }^{5}$ Since counting of mitotic figures is not entirely objective, attempts have been made to automate the counting of mitotic figures. Kaman et al described a first setup of an image analysis system for automated recognition of mitotic figures in $\mathrm{H} \& \mathrm{E}$ stained sections. ${ }^{11}$ Although this approach was partially successful, more recent approaches using Feulgen stained sections have been quite successful ${ }^{12}{ }^{13}$ and may serve as a prescreening device. In one study, mitotic figures were counted by flow cytometry using a combination of DNA fluorescence and right angle light scatter. ${ }^{14}$ The sensitivity and specificity of this method may, however, not be optimal. In principle, when a good mitotic figure marker becomes available (for example, the AF-2 protein ${ }^{15}$ ), flow cytometry for counting mitotic figures may be feasible.

Obviously, mitoses comprise only part of the proliferating cells. In addition, the length of the mitotic phase may be highly variable (especially in DNA aneuploid tumours) and there are indications that in some tumours, such as Hodgkin's lymphomas, even metaphase arrests may occur, so that a mitotic count does not necessarily provide a good marker of proliferation in all situations. ${ }^{16}$ Indeed, the mitotic index only partially correlates with other proliferation markers such as the Ki67 labelling index ${ }^{15}$ 17-19 and bromodeoxyuridine incorporation. ${ }^{20}$ In spite of these objections, mitosis counting has proven to be useful for many diagnostic applications. Reproducibility of mitosis counting is good if a strict counting protocol is followed, as has been shown in a large interlaboratory reproducibility study. ${ }^{5}$ Proper fixation and staining as well as standardised section thickness are mandatory to obtain reliable counts, although some fixation delay is acceptable if the tissue is kept in the refrigerator. ${ }^{21}{ }^{22}$

DNA CYTOMETRIC \%S-PHASE

In DNA cytometry, cell nuclei are stained with a stoichiometric DNA binding stain, and the amount of staining is measured. One popular approach is flow cytometry, whereby nuclei in a cell suspension are stained with a fluorescent dye, sucked into the flow cytometer where the fluorescence is excited, and measured by means of a photomultiplier system. Another approach that has become more popular in 
recent years is by image (or static) cytometry, where an absorption stain (the Feulgen reaction) is applied to cells on a glass slide, and the optical density is measured by image analysis. The result of both approaches is a frequency histogram of DNA content, the DNA histogram. The DNA histogram is in fact a representation of the cell cycle, and the fractions of cells within the different cell cycle phases $\left(G_{0} / G_{1}, S\right.$ and $G_{2} / M$ phases $)$ can be calculated from this histogram by computerised cell cycle analysis. The most widely used proliferation variable derived from DNA cytometry is the $\% \mathrm{~S}$-phase cells, although in fact the $S+G_{2} / M$ phase would represent the total proliferative fraction should the cells in $G_{1}$ that have passed the restriction point be neglected.

Traditionally, flow cytometry yields more reliable \%S-phase calculations than static DNA histograms because of the higher resolution of the DNA histograms, which is related to the accuracy of measurement and number of events measured. However, increased computer power and more sophisticated software, allowing more events to be measured, have made $\%$ S-phase calculations from static DNA cytometric histograms a valuable alternative for those derived from flow cytometry. ${ }^{23}$ $\%$ S-phase cells has been shown to correlate with other proliferation markers like $\mathrm{Ki} 67$ score $^{151824}$ and mitotic count, ${ }^{2526}$ although not very strongly.

With regard to reliability of \%S-phase assessments, several problems have been encountered in computerised cell cycle analysis. These are to a large extent caused by the different approach of the available programs and the different cell cycle fitting options within these programs, and partly to interobserver variations in interpretation. Nevertheless, some large studies have yielded important data as to the optimal fitting options, ${ }^{27-29}$ which may contribute to more consensus on cell cycle analysis. It seems that best results are obtained when using a semiautomated type of analysis. ${ }^{30}$ Fixation delay does not seem to affect \%S-phase measurements. ${ }^{2122}$

IMMUNOHISTOCHEMISTRY OF PROLIFERATION ASSOCIATED ANTIGENS

The proliferating cell nuclear antigen (PCNA) is a proliferation related protein that is upregulated in proliferating cells. Expression of PCNA correlates partly with other proliferation markers such as \%S-phase fraction, ${ }^{31-33}$ Ki67 staining, ${ }^{34}$ and mitotic count. ${ }^{32}$ Not all studies, however, have confirmed the correlation with mitotic count, ${ }^{35}$ and the PCNA labelling index could not be correlated with the Ki67 labelling index. ${ }^{36}$ This is probably owing to the fact that PCNA is also involved in DNA repair. Since there is active ongoing DNA repair in many tumours, PCNA may also be up regulated in non-proliferating cells. Indeed, in some tumours, $100 \%$ of cells show positive staining. Therefore, after an initial period of popularity, PCNA is not considered to be a very reliable proliferation marker in tumours.
The Ki67 antigen, which is coded by a gene on chromosome 10 , is expressed in the G1, S, and G2 phases in cycling cells. ${ }^{37} 38$ The Ki67 score partly correlates with other proliferation markers like \%S-phase cells, ${ }^{15} 182426$ and mitotic count. ${ }^{17-19}{ }^{36-49}$ Originally, the Ki67 antigen could only be studied in frozen sections. Recently, a series of Ki67 antibodies has been developed by the Kiel group that also works on paraffin embedded tumour material after antigen retrieval ${ }^{37} 38$ - the MIB antibodies. Of these, MIB-1 has been studied most widely and is regarded as a reliable marker of proliferating cells. MIB-1 assessments in paraffin sections are more reproducible than their counterparts in frozen sections. ${ }^{42}{ }^{43}$ Adequate methodology is important to obtain reproducibility. To this end, a systematic random sampling procedure based on stereology has been proposed to obtain unbiased sampling of nuclei to be scored. ${ }^{44}{ }^{45}$ Particularly when this is done with an automated scanning stage, quick and reproducible results are obtained. ${ }^{46}$

DNA topoisomerase II catalyses the topologic isomerisation of DNA by passing one strand of DNA through a reversible break in a second DNA strand. The expression of DNA topoisomerase II increases rapidly at the transition of the $S$ to $G_{2}$ phase and decreases rapidly at the end of mitoses. DNA topoisomerase II can be demonstrated by immunohistochemistry and can therefore be used as a marker of proliferating cells. There are as yet few applications of DNA topoisomerase II immunohistochemistry.

\section{AgNORS}

The nucleolus plays an essential role in the control of proliferation and protein synthesis. Nucleolar organiser regions (NORs) are segments of DNA closely associated with nucleoli which contain coding genes for ribosomal DNA. They therefore contribute strongly to the regulation of protein synthesis. NORs are argyrophylic and can therefore be visualised by a silver staining technique, what has led to the term AgNOR. AgNOR assessment correlates with rate of proliferation estimated by $\mathrm{Ki} 67$ score, ${ }^{19} 47 \%$ S-phase cells, ${ }^{48-50}$ and mitotic count. $^{48}$ More importantly, AgNOR assessments can probably be used to estimate cell cycle time, since the shorter the cell cycle, the more protein synthesis must take place for a subsequent mitoses per unit of time, so the more ribosomes must be generated and the higher the AgNOR score. AgNOR score has indeed been shown to correlate with population doubling time. ${ }^{51}$ There is, however, also protein synthesis activity in non-cycling cells, leading to a variable "baseline" AgNOR score. AgNORs as a measure of cell cycle time should therefore exclusively be assessed in proliferating cells, which can be done, for example, by double staining with $\mathrm{Ki} 67 .{ }^{52}$ Standardised staining technique and measurement protocols have been prepared and are presently under evaluation to deal with silver staining variability and unified scoring of AgNORs (number $v$ area, and so on), but at present these methods are difficult to apply in daily practice. 
The problem of heterogeneity

Heterogeneity is one of the hallmarks of malignancy in general, and this also holds for proliferation. Heterogeneity for several proliferation markers has been well documented for several tumour types such as mitosis counting, ${ }^{53}$ $\%$ S-phase, ${ }^{54}$ and Ki67 labelling ${ }^{55}$ in breast cancer, and for $\%$ S-phase ${ }^{56}$ and Ki67 index ${ }^{57}$ in gliomas, MIB-1 labelling index in squamous cell cancers of the head and neck ${ }^{58}$ and gastrointestinal adenocarcinomas, ${ }^{59}{ }^{60}$ and MIB1 labelling in lymphomas. ${ }^{61}$ In general, the highest proliferative part of the tumour will determine the clinical behaviour, so this must carefully be sought. With non-morphological methods such as DNA cytometric \%S-phase determinations this is hardly possible, which explains the lack of agreement about the clinical value of this proliferation variable in different tumours such as breast cancer. ${ }^{28}$ However, with morphological methods such as mitosis counting ${ }^{53}$ it is possible to deal with heterogeneity by screening different tumour parts for the highest proliferative area. From a clinical point of view, morphological methods of assessing proliferation will therefore in general be preferable.

The frequently expressed requirement for a statistical representation of any index or score at the level of the malignant population should be considered as a false problem if the tumour is comprised of subpopulations with different kinetic behaviour. In this case proliferation has to be evaluated wherever it is high in the tumour, and there is no biological reason for averaging the indices observed with respect to regions where malignant cells are proliferating poorly or not at all. Sampling statistics might merely erase potentially meaningful signals like nests of mitoses or cycling cells. In this context, "cellular sociology" concepts-where proliferation indices are related to topography-will most probably change the conventional sampling rules.

\section{Proliferation markers for diagnosis making and prognostication of tumours BREAST}

Breast cancer is probably the tumour in which the clinical implications of proliferation have been most studied. Several studies by different groups have been devoted to thymidine labelling, showing that high labelling indices are associated with poor prognosis; these have included large studies in node negative patients. ${ }^{62}{ }^{63}$ As to mitosis counting, the number of mitotic figures assessed in cytological specimens has prognostic value in breast cancer as part of a cytological grading system. ${ }^{64}$ Furthermore, it is also part of the prognostic histological grading system. ${ }^{65}{ }^{66}$ Several studies have shown that the number of mitotic figures is the most important prognostic component of the Bloom-Richardson histological grade. ${ }^{67-69}$ In several retrospective and prospective studies, Baak et al showed that a highly systematised way of assessing the mitotic activity index (MAI) gave very useful prognostic information over and above that provided by tumour size and lymph node status, ${ }^{70-81}$ which was confirmed by others. ${ }^{82}$ The prognostic results from a large prospective multicentre study by are eagerly awaited. ${ }^{83}$ Several other groups from different countries have confirmed the prognostic value of mitosis counting in invasive breast cancer. ${ }^{484967788284-89}$ The fact that the prognostic value of the MAI holds for premenopausal lymph node negative patients ${ }^{73}$ has led to a clinical trial throughout Europe in which high risk (MAI $\geqslant 10$ ), premenopausal, lymph node negative patients with invasive breast cancer are randomised over six cycles of CMF adjuvant chemotherapy or observation.

There have been many studies addressing the prognostic value of flow cytometrically assessed \%S-phase cells in breast cancer (for an overview, see Bergers $e t a l^{28}$ ). In some there has been no prognostic value, but most studies using fresh/frozen material and sufficient numbers of patients show a significantly worse prognosis for high \%S-phase values. Overall, one can therefore conclude that $\% \mathrm{~S}$-phase cell count has prognostic value in invasive breast cancer, although the differences in survival are small. Intratumour heterogeneity is a major problem, ${ }^{54}{ }^{90}$ as is the rather systematic correlation between increased $\% S$ phase and increased aneuploidy which indicates a potential bias.

The Ki67 labelling index was found to be prognostically relevant in several studies. ${ }^{39} 419192$ More recent studies using MIB1 paraffin antibody have confirmed its prognostic value. ${ }^{93-98}$ One comparative prognostic study between Ki67 and MIB-1 showed that MIB-1 assessments on paraffin are at least as good as the Ki67 assessments on frozen sections..$^{99}$

Conflicting prognostic results for the PCNA index have been presented, ${ }^{100-102}$ so PCNA does not seem to be a relevant prognostic variable in breast cancer for technical reasons.

OVARY

Assessment of prognosis of borderline tumours of the ovary based only on morphological criteria is difficult, and proliferation markers are of value here. Sumithran et al showed that grading of borderline tumours by applying mitotic figure counts was of prognostic value. ${ }^{103}$ Baak et al showed that the mitotic index (MI), assessed in the most epithelium-rich area of the tumour, exceeded the prognostic value of histological type, nuclear and histological grade, and even that of extent of disease. ${ }^{104}$ Patients with high MI were at high risk, and the MI also has value additional to DNA ploidy, which is probably the strongest prognostic indicator in these tumours. ${ }^{105}$ Others have described the importance of the presence of mitotic figures in peritoneal implants of borderline tumours. ${ }^{106}$

The patients with poor prognosis among early stage cancers can be identified using a combination of mitotic index and volume percentage of epithelium (VPE).$^{107-110}$ In advanced stage cancers, those cases with low MAI and low VPE seem to have a good chance of responding to cisplatin treatment, as shown by Baak et al and Rodenburg et al. ${ }^{111112}$ Haapasalo et al confirmed the prognostic value of the 
MAI/VPE combination for this group of patients, but showed that the $\mathrm{M} / \mathrm{V}$ index had greater prognostic value in ovarian cancers. ${ }^{110}$ $\%$ S-phase has also been shown to be of prognostic value in combination with DNA ploidy and psammoma body content ${ }^{113}$.

BONE TUMOURS

In osteosarcoma, mitotic activity seems to be one of the most important histological features for grading. ${ }^{114} 115$ The lower the mitotic rate, the better the chance of long term survival, although overall prognosis is relatively poor.

In chondroid tumours, counting mitotic figures helps to distinguish chondroma from chondrosarcoma. In the study of Cuvelier and Roels, ${ }^{116}$ none of 23 chondromas had more than one mitosis per 200 nuclei, only one of six low grade chondrosarcomas had one mitosis per 200 nuclei, and in the other cases the mitotic rate ranged between 2 and 5 . All high grade chondrosarcomas had higher mitotic rates, varying between 12 and 97. However, one chondroblastoma had a mitotic rate of 2 and one chondromyxoid fibroma a rate of 7 . Mitotic rates therefore have to be used in combination with histopathological criteria. In chondrosarcomas, the presence of two or more mitoses per HPF ( $\times 40$ objective) seemed to be the best indicator of metastases and poor prognosis in the study by Evans et al. ${ }^{117}$

In osteogenic fibrosarcoma, the mitotic frequency is the major histological feature in the grading system of the Netherlands Committee for Bone Tumours. ${ }^{118}$ Grade I tumours ( $<1$ mitosis/10 HPF) have a $65 \%$ five year survival and grade III tumours ( $\geqslant 10$ mitoses/10 $\mathrm{HPF}$ ) have only a $25 \%$ five year survival. Grade II has an intermediate prognosis.

In osteogenic giant cell tumours, mitotic activity is also used for grading. Grade I cases showing hardly any mitotic figures have a recurrence rate of about $10 \%$, grade II cases (more mitotic figures but still less than one per $\mathrm{HPF}$ ) have a recurrence rate of about $50 \%$, grade III (at least one mitosis per HPF) have a recurrence rate of about $80 \%$. Grade IV cases have all the features of sarcoma and are treated as such.

In aneurysmal bone cysts, mitotic activity can help to estimate the recurrence rate and to differentiate from telangiectatic osteosarcoma. Ruiter et al counted the number of mitosis per $50 \mathrm{HPF}\left(\times 750\right.$, field diameter $\left.275 \mu \mathrm{m}^{2}\right)$, and the recurrence rate was markedly higher in cases with more then seven mitoses (13/17 v $2 / 28) .{ }^{119}$ In combination with the area of the largest nucleus, this mitotic index was helpful in discriminating aneurysmal bone cysts from telangiectatic osteosarcoma. ${ }^{120}$

SOFT TISSUE TUMOURS

Assessment of malignancy in leiomyomatous tumours is a well recognised problem in which assessment of proliferation plays an important role. First, a discrimination has to be made between leiomyomatous tumours of the uterus and those in other sites. In extrauterine leiomyomatous tumours, a mitotic activity of five or more mitoses per $10 \mathrm{HPF}$ is a strong indicator of malignancy. In uterine leiomyomatous tumours, the situation is more complex. Classically, ${ }^{121}{ }^{122}$ leiomyomatous tumours with 5-9 mitoses per $10 \mathrm{HPF}$ were considered to be of "uncertain malignant potential," and with 10 or more mitoses per $10 \mathrm{HPF}$ to be malignant. However, there is a tendency to allow focally higher mitotic activity in younger women, especially in those using hormones. ${ }^{123}{ }^{124}$ Indeed, in recent studies on borderline uterine leiomyomatous tumours in pre- and postmenopausal women, it was shown that presence of tumour necrosis and significant nuclear atypia are the most important indicators of malignancy, ${ }^{125}{ }^{126}$ and that in the absence of significant nuclear atypia and tumour necrosis these tumours usually behave benignly, irrespective of the mitotic activity. When tumour necrosis or significant nuclear atypia is found, however, a high mitotic rate $(>10)$ indicates a clearly greater chance of relapse. There is no real consensus on the prognostic value of proliferation in true uterine leiomyosarcomas, ${ }^{126-128}$ and one study on uterine stromal nodules also did not find that this had any prognostic significance. ${ }^{129}$

In gastrointestinal stromal tumours (GIST), MIB-1 labelling index and mitotic index were both very significantly correlated with patient survival in a study by Carrillo et al. ${ }^{130}$ High proliferation is therefore an essential hallmark of high risk in these tumours, which is otherwise difficult to identify.

In soft tissue sarcomas, proliferation was found to be of prognostic value in several studies. High proliferation, as reflected by high mitotic index ${ }^{131-137}$ high $\mathrm{Ki67}$ labelling index, ${ }^{137-140}$ and high $\%$ S-phase cells ${ }^{137} 141142$ are indicators of poor prognosis in these malignancies. Several sarcoma grading systems that include a measure of proliferation have been proposed. Myhre Jensen et al combined mitotic index with cellularity, cellular anaplasia, and the presence of pyknotic or fragmented nuclei, ${ }^{132}$ and Coindre et al proposed a multivariate combination of mitotic index, cellular differentiation, and tumour necrosis. ${ }^{135}$ Probably the most widely applied grading system for (locally adequately treated) sarcomas is that of the EORTC, including mitotic index only: patients with fewer than three mitoses per $2 \mathrm{~mm}^{2}$ (grade I) do very well; patients with more than 25 mitoses per $2 \mathrm{~mm}^{2}$ (grade III) do very poorly; and grade 2 patients with 4-25 mitoses per $2 \mathrm{~mm}^{2}$ (grade II) have intermediate prognosis. ${ }^{133134}$ Combining mitotic index with necrosis and tumour size provided the best results.

\section{BRAIN TUMOURS}

Mitoses play a role in the grading system of astrocytomas developed by Daumas-Duport et al. A point each is given for presence of nuclear atypia, mitoses, endothelial proliferation, and necrosis. This grading system is very reproducible and correlates well with prognosis. ${ }^{143}$

In meningiomas, the number of mitoses counted in 10 fields at $400 \times$ - grouped as 0,1 , $2-5$, or 5 or more-correlates significantly with recurrence after subtotal resection. ${ }^{144}$ 
LYMPHOMAS

Akerman et al counted mitotic figures in 101 non-Hodgkin's lymphomas. ${ }^{145}$ Those patients with on average more than two mitoses per $400 \times$ field (counted in 10 fields) had a $37 \%$ two year survival, while cases with fewer than two mitoses an average had a $77 \%$ survival at that time. For follicle centre cell lymphomas, the prognostic value of their mitotic index exceeded that of growth pattern and predominant cell type. Griffin et al found comparable results. ${ }^{146}$ Ki67 labelling index has also been shown to provide prognostic information in non-Hodgkin's lymphomas. ${ }^{147-150}$

CERVIX

In normal cervix, proliferating cells are confined to the parabasal layer. This also holds for atrophic epithelium, koilocytic epithelium, and immature squamous metaplasia-conditions that may be difficult to distinguish from dysplastic epithelium. As has been shown in several studies, ${ }^{151-154}$ proliferation is increased in dysplastic epithelium, to an extent that correlates well with the grade of dysplasia. In addition, the higher the grade of dysplasia, the higher up in the epithelium are proliferating cells found (as demonstrated by MIB-1 immunohistochemistry). This topographical MIB-1 labelling index can therefore be useful to discriminate dysplastic epithelium from conditions mimicking dysplasia, as well as for grading dysplasia.

\section{Conclusion}

Several routinely applicable techniques have become available that reveal different properties of proliferation, all having their advantages and disadvantages. However, since cell cycle time is as yet very difficult to assess, they do not provide accurate information on rate of proliferation as such, but rather on the state of proliferation at the time of assessment. ${ }^{155}$ Nevertheless, several of these methods have found their way into daily pathology practice, where they provide useful diagnostic and prognostic information in lesions and tumours from several sites. More methodological studies are necessary before reproducible protocols become available that provide similar information in different laboratories; the problem of heterogeneity must also be adequately dealt with, owing to the significant heterogeneity of most types of tumours. Although growth is obviously the net effect of proliferation and cell death, cell death is as yet difficult to quantify, although some attempts have been made. ${ }^{156}$ Although some interesting results have been described, the lack of reliable data on the duration of cell death events hampers these attempts.

1 Quastler H, Sherman FG. Cell population kinetics in the intestinal epithelium of the mouse. Exp Cell Res 1959;17:420-38

2 Meyer JS, McDivitt RW. Reliability and stability of the thymidine labeling index of breast carcinoma. Lab Invest 1986;54:160-4.

3 Baak JPA. Manual of quantitative pathology in cancer diagnosis and prognosis. Berlin: Springer Verlag, 1991 .

4 Baak JPA. Mitosis counting in tumors. Hum Pathol 1990;21: $683-5$.
5 van Diest PJ, Baak JPA, Matze-Cok P, et al. Reproducibility of mitosis counting in 2469 breast cancer specimens: results from the multicenter morphometric

6 Woosley JT. Measuring cell proliferation. Arch Pathol Lab Med 1991;115:555-7.

7 Haapasalo H, Pesonen E, Collan Y. Volume corrected mitotic index (M/V-index). The standard of mitotic activity in neoplasms. Pathol Res Pract 1989;185:551-4.

8 Going JJ. Efficiently estimated histologic cell counts. Hum Pathol 1994;25:333-6.

9 Simpson JF, Dutt PL, Page DL. Expression of mitoses per thousand cells and cell density in breast carcinomas: a proposal. Hum Pathol 1992;23:608-11.

10 Collan YUI, Kuopio T, Bak JPA, et al. Standardized mitotic counts in breast cancer. Evaluation of the method. Pathol Res Pract 1996;192:931-41.

11 Kaman EJ, Smeulders AWM, Verbeek PW, et al. Image processing for mitoses in sections of breast cancer: a feasibility study. Cytometry 1984;5:244-9.

12 Belien JAM, Baak JPA, van Diest PJ, et al. Counting mitoses by image processing in Feulgen stained breast cancer sections: the influence of resolution. Cytometry 1997;28: $135-40$.

13 ten Kate TK, Belien JAM, Smeulders AWM, et al. Method for counting mitoses by image processing in Feulgen stained breast cancer sections. Cytometry 1993;14:241-50.

14 Zucker RM, Elstein KH, Easterling RE, et al. Flow cytometric discrimination of mitotic nuclei by right-angle cytometric discrimination of mitotic nucle

15 di Vinci A, Geido E, Pfeffer U, et al. Quantitative analysis of mitotic and early-G1 cells using monoclonal antibodies against the AF-2 protein. Cytometry 1993;14:421-7.

16 Spina D, Leoncini L, Close P, et al. Growth versus DNA strand breaks in Hodgkin's disease: impaired proliferative ability of Hodgkin and Reed-Sternberg cells. Int $\mathcal{F}$ Cancer 1996;66:179-83.

17 Barnard NJ, Hall PA, Lemoine NR, et al. Proliferative index in breast carcinoma determined in situ by Ki67 immunostaining and its relationship to clinical and pathological variables. 7 Pathol 1987;152:287-95.

18 Isola JJ, Helin HJ, Helle MJ, et al. Evaluation of cell proliferation in breast carcinoma. Comparison of Ki-67 immunohistochemical study, DNA flow cytometric analysis, and mitotic count. Cancer 1990;65:1180-4

19 di Stefano D, Mingazzini PL, Scucchi L, et al. A comparative study of histopathology, hormone receptors, peanut lectin binding, Ki-67 immunostaining, and nucleolar organizer region-associated proteins in human breast cancer. Cancer 1991;67:463-71.

20 Weidner N, Moore DH, Ljung BM, et al. Correlation of bromodeoxyuridine (BRDU) labeling of breast carcinoma cells with mitotic figure content and tumor grade. $A m$ f Surg Pathol 1993;17:987-94.

21 Bergers E, Jannink I, van Diest PJ, et al. Influence of fixation delay on mitotic activity and flow cytometric \%S-phase. Hum Pathol 1997;28:95-100.

22 Donhuijsen $\mathrm{K}$, Schmidt U, Hirche $\mathrm{H}$, et al. Changes in mitotic rate and cell cycle fractions caused by delayed fixation. Hum Pathol 1990;21:709-14.

23 Montironi R, Diamanti L, Santinelli A, et al. Computed cell cycle and DNA histogram analysis in image cytometry in breast cancer. F Clin Pathol 1993;46:795-800.

24 Walker RA, Gallacher B. Determination of transforming growth factor beta $1 \mathrm{mRNA}$ expression in breast carcinomas by in situ hybridization. $\mathcal{F}$ Pathol 1995;177:123-7.

25 Bosari S, Lee AKC, Tahan SR, et al. DNA flow cytometric analysis and prognosis of axillary lymph node-negative breast carcinoma. Cancer 1992;70:1943-50.

26 Lee AKC, Wiley B, Dugan JM, et al. Quantitative DNA analysis and proliferation in breast carcinomas. A comparison between image analy

27 Bergers E, van Diest PJ, Baak JPA. Comparison of 5 cell cycle analysis models applied to 1414 flow cytometric DNA histograms of fresh frozen breast cancer. Clin Commun Cytometry 1997;30:54-60.

28 Bergers E, van Diest PJ, Baak JPA. Prognostic implications of different cell cycle analysis models of flow cytometric DNA histograms of 1301 breast cancer patients: results from the multicenter morphometric mammary carcinoma project. Int $\mathcal{F}$ Cancer 1997;74:260-9.

29 Kallioniemi OP, Visakorpi T, Holli K, et al. Improved prognostic impact of S-phase values from paraffin-embedded breast and prostate carcinomas after correcting for nuclear slicing. Cytometry 1991;12:413-21.

30 Bergers E, Montironi R, van Diest PJ, et al. Inter-laboratory reproducibility of semiautomated cell cycle analysis of flow cytometric DNA-histograms obtained from fresh material of 1295 breast cancer cases. Hum Pathol 1996;27:553-60.

31 Garcia JE, Celis A. Cell-cycle dependent variations in the distribution of the nuclear protein cyclin proliferating cell nuclear antigen in cultured cells: subdivision in S-phase. Proc Natl Acad Sci USA 1985;82:3262-6.

32 Siitonen SM, Kallioniemi OP, Isola JJ. Proliferating cell nuclear antigen immunohistochemistry using monoclonal antibody $19 \mathrm{~A} 2$ and a new antigen retrieval technique has prognostic value in archival paraffin-embedded nodenegative breast cancer. Am f Pathol 1993;142:1081-9.

33 Visscher DW, Wykes S, Kubus J, et al. Comparison of PCNA/cyclin immunohistochemistry with flow cytometric S-phase fraction in breast cancer. Breast Cancer Res Treat 1992;22:111-18. 
34 van Dierendonck JH, Wijsman JH, Keijzer $\mathrm{R}$, et al. Cell-cycle-related staining patterns of anti-proliferating cell nuclear antigen BrdUrd labeling and Ki67 staining. Am f Pathol 1991;138 1165-72

35 Schmitt FC, Pereira EM, Andrade LM, et al. The proliferating cell nuclear antigen index in breast carcinomas does no correlate with mitotic index and estrogen receptor. Pathol Res Pract 1994;190:786-91.

36 Leonardi E, Girlando S, Serio G, et al. PCNA and Ki67 expression in breast carcinoma: correlations with clinical and biological variables. F Clin Pathol 1992;45:416-19.

37 Gerdes J, Becker MHG, Key G, et al. Immunohistological detection of tumour growth fraction (Ki-67 antigen) in formalin-fixed and routinely processed tissues [letter]. $\mathcal{F}$ Pathol 1992;174:1685-7.

38 Guillaud P, de Manoir S, Geigneurin D. Quantification and topographical description of $\mathrm{Ki}-67$ antibody labelling during the cell cycle of normal fibroblastic (MRC-5) and ing the cell cycle of normal fibroblastic (MRC-5) and mammary tum

39 Bouzubar N, Walker KJ, Griffiths K, et al. Ki67 immunostaining in primary breast cancer: pathological and clinical associations. Br f Cancer 1989;59:943-7

40 Marchetti E, Querzoli P, Marzola A, et al. Assessment of proliferative rate of breast cancer by Ki67 monoclonal antibody. Mod Pathol 1990;3:31-5.

41 Sahin AA, Ro J, Ro JY, et al. Ki-67 immunostaining in node-negative stage I/II breast carcinoma. Significan correlation with prognosis. Cancer 1991;68:549-57.

42 Weidner N, Moore DH, Vartanian R. Correlation of Ki67 antigen expression with mitotic figure index and tumor grade in breast carcinomas using the novel "paraffin"reactive MIB1 antibody. Hum Pathol 1994;25:337-42.

43 Barbareschi M, Girlando S, Mauri FM, et al. Quantitative growth fraction evaluation with MIB1 and Ki67 antibodies in breast carcinomas. Am f Clin Pathol 1994;102:171-5.

44 Polkowski W, Meijer GA, Baak JP, et al. Reproducibility of p53 and Ki67 immunoquantitation in Barret's esophagus. Anal Quant Cytol Histol 1997;19:246-54.

45 van Diest PJ, van Dam P, Henzen-Logmans SC, et al. A scoring system for immunohistochemical staining: consensus report of the task force for basic research of the EORTC-GCCG. F Clin Pathol 1997;50:801-4.

46 Oudejans JJ, Jiwa NM, Kummer JA, et al. Activated cytotoxic T-cells as prognostic marker in Hodgkin's disease. Blood 1997;89:1376-82.

47 Dervan PA, Gilmartin LG, Loftus BM, et al. Breast carcinoma kinetics. Argyrophilic nucleolar organizer region counts correlate with Ki67 scores. Am f Clin Pathol 1989;92:401-7.

48 Aaltoma S, Lipponen P, Syrjanen K. Nucleolar organizer regions related to morphometry, flow cytometry, sex regions related to morphometry, flow cytometry, sex steroid receptor content, tumour histology and prognosis

49 Eskelinen M, Lipponen P, Papinaho S, et al. DNA flow cytometry, nuclear morphometry, mitotic indices and steroid receptors as independent prognostic factors in female breast cancer. Int $\mathcal{F}$ Cancer 1992;51:555-61.

50 Mourad WA, Erkman-Balis B, Livingston S, et al. Argyrophilic nucleolar organizer regions in breast carcinoma. Correlation with DNA flow cytometry, histopathology, and lymph node status. Cancer 1992;69:1739-44.

51 Öfner D, Hittmair A, Marth C, et al. Relationship between quantity of silver stained nucleolar organiser regions
associated proteins (Ag-NORs) and population doubling time in ten breast cancer cell lines. Pathol Res Pract 1992;188:742-6.

52 Bigras G, Marcelpoil R, Brambilla E, et al. Interest of targeting AgNORs measurement in cycling cells: in vivo cell ing AgNORs measurement in cycling cells: in vivo cell kinetic evaluation of no

53 Jannink I, Risberg B, van Diest PJ, et al. Heterogeneity of mitoses counting in breast cancer. Histopathology 1996;29: $421-8$

54 Bergers E, van Diest PJ, Baak JPA. Tumour heterogeneity of DNA cell cycle variables in breast cancer measured by flow cytometry. F Clin Pathol 1996;49:931-7.

55 Verhoeven D, Bourgeois N, Derde MP, et al. Comparison of cell growth in different parts of breast cancers. Histopathology 1990;17:505-9.

56 Coons SW, Johnson PC. Regional heterogeneity in the DNA content of human gliomas. Cancer 1993;72:3052-60.

57 Roessler K, Nasel C, Czech T, et al. Histological heterogeneity of neuroradiologically suspected low grade gliomas detected by xenon enhanced computerized tomography (CT). Acta Neurochir 1996;138:1341-7.

58 Jacob R, Welkoborsky HJ, Mann WJ, et al. Heterogeneity of squamous cell carcinomas of the head and neck-analysis of tumor biologic factors and proliferation rates. Laryngoscope 1996;106:1170-5.

59 Kressner U, Lindmark G, Gerdin B, et al. Heterogeneity in proliferation markers in colorectal cancer. Anticancer Res 1995; 15:2755-61

60 Muller W, Schneiders A, Meijer S, et al. Immunohistochemical study on the prognostic value of MIB-1 in gastric carcinoma. Br 7 Cancer 1996;74:759-65.

61 Barrans S, Randerson J, Evans P, et al. Heterogeneity in cell proliferation and expression of p53 and bcl-2 during indoproliferation and expere germinal centre cell lymphoma: an explanation for clinical variability. Br f Haematol 1995;90:830-6.

62 Tubiana M, Pejovic MH, Koscielny S, et al. Growth rate, kinetics of tumor cell proliferation, and long-term outcome in human breast cancer. Int $\mathcal{F}$ Cancer 1989;44:17-22.
63 Silvestrini R, Daidone MG, Luisi A, et al. Cell proliferation in 3,800 node-negative breast cancers: consistency over ime labelling index. Int f Cancer 1997;74:122-7.

64 Mouriquand J, Gozlan-Fior M, Villemain D, et al. Value of cytoprognostic classification in breast carcinomas. $f$ Clin Pathol 1986;39:489-96.

65 Bloom HJG, Richardson WW. Histological grading and prognosis in breast cancer. Br f Cancer 1957;11:359-77.

66 Elston CW, Ellis IO. Pathological prognostic factors in breast cancer. I. The value of histologic grade in breast cancer: experience from a large stud

67 le Doussal V, Tubiana-Hulin M, Friedman S, et al. Prognostic value of histologic grade nuclear components of ScarffBloom-Richardson (SBR). An improved score modification based on a multivariate analysis of 1262 invasive ductal breast carcinomas. Cancer 1989;64:1914-21.

68 Joensuu H, Toikkanen S, Klemi PJ. DNA index and S-phase fraction and their combination as prognostic factors in operable ductal breast carcinoma. Cancer 1990;66:331-40.

69 Elston CW. Grading of invasive carcinoma of the breast. In: Page DL, Anderson TJ, eds. Diagnostic histopathology of the breast. Edinburgh: Churchill Livingstone, 1987.

70 Baak JPA, Kurver PHJ, Snoo-Nieuwlaat AJE, et al. Prognostic indicators in breast cancer-morphometric methods. Histopathology 1982;6:327-39.

71 Baak JPA, van Dop H, Kurver PHJ, et al. The value of morphometry to classic prognosticators in breast cancer. Cancer 1985;56:374-82.

72 Baak JPA, Chin D, van Diest PJ, et al. Comparative long term prognostic value of quantitative Her2/Neu protein expression, DNA ploidy, morphometric and clinical features in paraffin-embedded invasive breast cancer. $L a b$ Invest 1991;64:215-22.

73 van Diest PJ, Baak JPA. The morphometric multivariate prognostic index (MPI) is the strongest prognosticator in premenopausal lymph node negative and lymph node posi-

4 van Diest PJ, Baak JPA, Matze-Cok P, et al. Prediction response to adjuvant chemotherapy in premenopausal lymph node positive breast cancer patients with morphometry, DNA flow cytometry and HER-2/neu oncoprotein pression: preliminary results. Pathol Res Pract 1992;188: pression:

75 van Diest PJ, Jannink I, Matze-Cok E, et al. Comparative prognostic value of lymph node metastases and primary four quantitative variables in breast cancer. Fournal of Pathology and Histology 1995;1:952-02.

76 van der Linden JC, Baak JPA, Lindeman J, et al. Prospective evaluation of the prognostic value of morphometry in primary breast cancer patients. F Clin Pathol 1987;40:302-

77 van der Linden JC, Lindeman J, Baak JPA, et al. The multivariate prognostic index and nuclear DNA content are independent prognostic factors in primary breast cancer patients. Cytometry 1989;10:56-61.

78 Tosi P, Luzi P, Sforza V, et al. Correlation between morphometrical parameters and disease free-survival in ductal breast cancer treated only by surgery. Appl Pathol 986;4:33-42.

79 Uyterlinde AM, Schipper NW, Baak JPA, et al. Limited prognostic value of cellular DNA content to classical and morphometrical parameters in invasive ductal breast cancer. Am F Clin Pathol 1988;89:301-7.

80 Uyterlinde AM, Baak JPA, Schipper NW, et al. Further evaluation of morphometric and flow cytometric features in breast cancer patients with long term follow up. Int $7 \mathrm{Can}-$ cer 1990;45:1-7.

81 Uyterlinde AM, Baak JPA, Schipper NW, et al. Prognostic value of morphometry and DNA flow cytometry features of invasive breast cancers detected by population screening: comparison with control group of hospital patients. Int $\mathcal{F}$ Cancer 1991;48:173-81.

82 Biesterfeld S, Noll I, Noll E, et al. Mitotic frequency as a prognostic factor in breast cancer. Hum Pathol 1995;26:47-

83 Baak JPA, van Diest PJ. The multicenter morphometric mammary carcinoma project. A nationwide prospective study on reproducibility and prognostic power of routine quantitative assessments in the Netherlands. Pathol Res Pract 1989;185:664-70.

84 Aaltomaa S, Lipponen P, Eskelinen M, et al. Prognostic factors in axillary lymph node-negative $(\mathrm{pN}-)$ breast carcinomas. Eur 7 Cancer 1991;27:1555-9.

85 Aaltomaa S, Lipponen P, Eskelinen M, et al. Prognostic factors after 5 years follow-up in female breast cancer. Oncology 1992;49:93-8.

86 Aaltoma S, Lipponen P, Papinaho S, et al. Proliferating-cell nuclear antigen (PC10) immunolabelling and other proliferation indices as prognostic factors in breast cancer. $\mathcal{F}$ Cancer Res Clin Oncol 1993;119:288-94.

87 Clayton F. Pathologic correlates of survival in 378 lymph node-negative infiltrating ductal breast carcinomas. Mitotic count is the best single predictor. Cancer 1991;68:1309-17.

88 Lipponen PK, Collan Y, Eskelinen MJ. Volume corrected mitotic index $(\mathrm{M} / \mathrm{V}$ index), mitotic activity index (MAI), and histological grading in breast cancer. Int $\mathcal{F}$ Surg 1991;76:245-9.

89 Lipponen P, Eskelinen M, Papinaho S, et al. Sex steroid receptors, S-phase fraction and DNA ploidy as determinants of the risk of relapse and death of female breast cancer. Anticancer Res 1992;12:667-82. 
90 Bonsing BA, Beerman H, Kuipers-Dijkshoorn N, et al. High levels of DNA index heterogeneity in advanced breast can levels of DNA index heterogen

91 Veronese SM, Gambacorta M, Gottardi O, et al. Proliferation index as a prognostic marker in breast cancer. Cancer 1993;71:3926-31.

92 Wintzer HO, Zipfel I, Schulte-Moenting J, et al. Ki67 immunostaining in human breast tumors and its relationship to prognosis. Cancer 1991;67:421-8.

93 Beck T, Weller EE, Weikel W, et al. Usefulness of immunohistochemical staining for p53 in the prognosis of breast carcinomas: correlations with established prognosis parameters and with the proliferation marker, MIB-1. Gynecol Oncol 1995;57:96-104.

94 Dettmar P, Harbeck N, Thomssen C, et al. Prognostic impact of proliferation-associated factors MIB1 and S-phase in node-negative breast cancer. Br f Cancer 1997; 75:1525-33.

95 Jensen V, Ladekarl M, Holm-Nielsen P, et al. The prognostic value of oncogenic antigen 519 (OA-519) expression and proliferative activity detected by antibody MIB-1 in node negative breast cancer. F Pathol 1995;176:343-52.

96 MacGrogan G, Mauriac L, Durand M, et al. Primary chemotherapy in breast invasive carcinoma: predictive value of the immunohistochemical detection of hormonal receptors, p53, c-erbB-2, Mib 1,pS2 and GST pi. Br $\mathcal{F}$ Cancer 1996;74:1458-65.

97 Pietilainen T, Lipponen P, Aaltomaa S, et al. The important prognostic value of $\mathrm{Ki}-67$ expression as determined by image analysis in breast cancer. 7 Cancer Res Clin Oncol 1996;122:687-92.

98 Pinder SE, Wencyk P, Sibbering DM, et al. Assessment of the new proliferation marker MIB1 in breast carcinoma using image analysis: associations with other prognostic factors and survival. Br f Cancer 1995;71:1546-9.

99 Veronse SM, Maisano C, Scibilia J. Comparative prognostic value of $\mathrm{Ki}-67$ and MIB-1 proliferation markers in breast value of Ki-67 and MIB-1 proliferation

100 Schoenborn I, Minguillon C, Moehner M, et al. PCNA as a potential prognostic marker in breast cancer. Breast 1994

101 Tahan SR, Neuberg DS, Dieffenbach A, et al. Prediction of early relapse and shortened survival in patients with breast scell nuclear antigen score. Cancer 1993;71:3552-9.

102 Thomas M, Noguchi M, Kitagawa H, et al. Poor prognostic value of proliferating cell nuclear antigen labelling index in breast carcinoma. $\mathcal{F}$ Clin Pathol 1993;46:525-8.

103 Sumithran E, Susil BJ, Lai-Leng-Looi. The prognostic significance of grading in borderline mucinous tumours of the nificance of grading in borderline 18 .

104 Baak JPA, Fox H, Langley FA, et al. The prognostic value of morphometry in ovarian epithelial tumors of borderline of morphometry in ovarian epithelial tumors of

105 Baak JPA, Abeler V, Broeckaert MAM, et al. Morphometry and DNA cytometry have strong and additional prognostic value in borderline ovarian tumours with long term follow up [abstr]. $\mathcal{F}$ Pathol 1995;176:49A.

106 Bell DA, Weinstock MA, Scully RE. Peritoneal implants of ovarian serous borderline tumors. Histologic features and prognosis. Cancer 1988;62:2212-22.

107 Baak JPA, Wisse-Brekelmans ECM, Langley FA, et al. Morphometric data to FIGO stage and histological type and grade for prognosis of ovarian tumours. $\mathcal{F}$ Clin Pathol 1986;39:1340-6.

108 Baak JPA. Prognostic value of histopathological morphometry in endocrine-related cancer. Rev Endocr Rel Cancer 1987;27:21-4.

109 Haapasalo H, Collan Y, Atkin NB, et al. Prognosis of ovarian carcinomas: prediction by histoquantitative methods. Histopathology 1989;15:167-78.

110 Haapasalo H, Collan Y, Seppa A, et al. Prognostic value of ovarian carcinoma grading methods - a method comparison study. Histopathology 1990;16:1-7.

111 Baak JPA, Schipper NW, Wisse-Brekelmans ECM, et al. The prognostic value of morphometrical features and cellular DNA content in cis-platin treated late ovarian cancer patients. Br f Cancer 1988;57:503-8.

112 Rodenburg CJ, Cornelisse CJ, Hermans J, et al. DNA flow cytometry and morphometry as prognostic indicators in advanced ovarian canc clinical outcome. Gynecol Oncol 1988;29:176-87.

113 Kuhn W, Kaufmann M, Feichter GE, et al. Psammoma body content and DNA flow cytometric results as prognostic factors in advanced ovarian carcinoma. Eur f Gynaecol Oncol 1988;9:234-41.

114 van der Heul R. Het periostale ossificerende fibrosarcoom en de gradering van osteosarcomen. Leiden: University of Leiden, 1962 [thesis]

115 Price CHG. Osteogenic sarcoma. An analysis of survival and its relationship to histologic grading and structure. $\mathcal{F}$ Bone foint Surg [Br] 1961;43:300-13.

116 Cuvelier CA, Roels HJ. Cytophotometric studies of the nuclear DNA content in cartilaginous tumours. Cancer 1979;44:1363-74.

117 Evans HL, Ayala AG, Romsdahl MM. Prognostic factors in chondrosarcoma of bone. A clinicopathologic analysis with emphasis on histologic grading. Cancer 1977;40:81831 .

118 van der Werff-Messing B, van Unnik JAM. Fibrosarcoma of the soft tissues. Cancer 1965;18:1113-23.

119 Ruiter DJ, van Rijssel TG, van der Velde EA. Aneurysmal bone cysts. A clinicopathological study of 105 cases. Cancer 1977;39:2231-9.
120 Ruiter DJ, Cornelisse CJ, van Rijssel TG, et al. Aneurysmal bone cyst and teleangiectatic osteosarcoma. Virchows Arch [A] 1977;373:311-25.

121 Enzinger FM, Weiss SW. Benign tumors of smooth muscle. In: Enzinger FM, Weiss SW, eds. Soft tissue tumors. St Louis: CV Mosby, 1988:385

122 Zaloudek C, Norris HJ. Mesenchymal tumors of the uterus. In: Kurman RJ, ed. Blaustein's pathology of the female genital tract. New York: Springer, 1987:385.

123 Prayson RA, Hart WR. Mitotically active leiomyomas of the uterus. Am f Clin Pathol 1992;97:14-20.

124 Rosai J. Female reproductive system/uterus-corpus. In: Rosai J, ed. Ackerman's surgical pathology. St Louis: CV Mosby, 1989:1088.

125 Bell SW, Kempson RL, Hendrickson MR. Problematic uterine smooth muscle neoplasms. Am F Surg Pathol 1994; 18:535-58.

126 Jeffers MD, Oakes SJ, Richmond JA, et al. Proliferation, ploidy and prognosis in uterine smooth muscle tumours. Histopathology 1996;29:217-23.

127 Amada S, Nakano H, Tsuneyoshi M. Leiomyosarcoma vs bizarre and cellular leiomyomas of the uterus: a comparative study based on the Ki67 and proliferating cell nuclear antigen indices, p53 expression, DNA flow cytometry and muscle specific antigens. Int $\mathcal{F}$ Gynecol Pathol 1995;14:13442 .

128 Larson B, Silfersward C, Nilsson B, et al. Prognostic factors in uterine leiomyosarcoma. A clinical and histopathological study of 143 cases. The Radiumhemmet series 1936-1981. Acta Oncol 1990;29:185-91.

129 Tavassoli FA, Norris HJ. Mesenchymal tumors of the uterus. VII. A clinicopathological study of 60 endometrial stromal nodules. Histopathology 1981;5:1-10.

130 Carrillo R, Candia A, Rodriques-Peralto JL, et al. Prognostic significance of DNA ploidy and proliferative index (MIB-1 index) in gastrointestinal stromal tumors. Hum Pathol 1997;28:160-5.

131 Michie BA, Black C, Reid RP, et al. Image analysis derived ploidy and proliferation indices in soft tissue sarcomas: comparison with clinical outcome. F Clin Pathol 1994;47: 443-7.

132 Myhre Jensen O, Kaae S, Madsen HE, et al. Histopathoogical grading in soft tissue tumours. Relation to survival in 261 surgically treated patients. Acta Pathol Microbiol Scand [A] 1983;91:145-51.

133 van Unnik JAM, Coindre JM, Contesso G, et al. Grading of soft tissue sarcomas: experience of the EORTC Soft Tissue and Bone Sarcoma Group. In: Ryan JR, Baker LO, eds. Recent concepts in sarcoma treatment. Dordrecht: Kluwer, 1988.

134 van Unnik JAM, Coindre JM, Contesso G, et al. Grading of soft tissue sarcomas: experience of the EORTC Soft Tissue and Bone Sarcoma Group. Eur $\mathcal{F}$ Cancer 1993;29A: 2089-93.

135 Coindre JM, Trojani M, Contesso G, et al. Reproducibility of a histopathologic grading system for adult soft tissue sar-

136 Rooser BO, Willen H, Hugoson A, et al. Prognostic factors in synovial sarcoma. Cancer 1989;63:2182-5.

137 Rudolph P, Kellner U, Chassevent A, et al. Prognostic relevance of a novel proliferation marker, Ki-S11, for soft-tissue sarcoma. A multivariate study. Am $\mathcal{F}$ Pathol 1997;150:1997-2007.

138 Choong PF, Akerman M, Willen $\mathrm{H}$, et al. Expression of proliferating cell nuclear antigen (PCNA) and Ki-67 in soft tissue sarcoma. Is prognostic significance histotypetissue sarcoma. Is prognostic sic
specific? APMIS 1995; 103:797-805.

139 Drobnjak M, Latres E, Pollack D, et al. Prognostic implications of p 53 nuclear overexpression and high proliferation index of Ki-67 in adult soft-tissue sarcomas. 7 Natl Cancer Inst 1994;86:549-54.

140 Levine EA, Holzmayer T, Bacus S, et al. Evaluation of newer prognostic factors for adult soft tissue sarcomas. $\mathcal{F}$

41 Collin F, Chassevent A, Bonichon F, et al. Flow cytometric DNA content analysis of 185 soft tissue neoplasms indicates that S-phase fraction is a prognostic factor for sarcomas. Cancer 1997;79:2371-9.

142 Schmidt RA, Conrad EU, Collins C, et al. Measurement and prediction of the short-term response of soft tissue sarcomas to chemotherapy. Cancer 1993;72:2593-601

143 Daumas-Duport C, Scheithauer B, O'Fallon J, et al. Grading of astrocytomas. A simple and reproducible method. Cancer 1988;62:2152-65.

144 de la Monte SM, Flickinger J. Histopathologic features predicting recurrence of meningeomas following subtotal predicting recurrence of meningeomas followin
resection. Am F Surg Pathol 1986;10:836-43.

145 Akerman M, Brandt L, Johnson S, et al. Mitotic activity in non-Hodgkin's lymphoma. Relation to the Kiel classification and to prognosis. Br f Cancer 1987;55:219-23.

146 Griffin NR, Howard MR, Quirke P, et al. Prognostic indicators in centroblastic-centrocytic lymphoma. $\mathcal{F}$ Clin Pathol 1988;41:866-70.

147 Schrape S, Jones DB, Wright DH. Comparison of three methods for the determination of the growth fraction in non-Hodgkin's lymphomas. Br f Cancer 1987;55:283-6.

148 Hall PA, Richard MA, Gregory WM, et al. The prognostic significance of Ki67 immunostaining in non-Hodgkin's lymphomas. F Pathol 1988;154:223-35.

149 Gerdes J, Stein H, Rivano MT, et al. Prognostic relevance of tumour cell growth fraction in malignant non-Hodgkin's lymphoma. Lancet 1987;ii:448-9.

150 Grogan TM, Lippman SM, Spier CM, et al. Independent prognostic significance of a nuclear proliferation antigen in 
diffuse large cell lymphomas as determined by the monoclonal antibody Ki-67. Blood 1988;71:1157-60.

151 Bulten J, van der Laak JAWM, Gemmink JH, et al. MIB1, promising marker for the classification of cervical intraepithelial neoplasia f Pathol 1996;178:268-73.

152 Dellas A, Schultheiss E, Holzgreve W, et al. Investigation of the Bcl-2 and C-myc expression in relationship to the Ki67 index in cervical intraepithelial neoplasia. Int $\mathcal{f}$ Gynecol Pathol 1997;16:212-18

153 McCluggage WG, Buhidma M, Tang L, et al. Monoclonal antibody MIB1 in the assessment of cervical squamous intraepithelial lesions. Int F Gynecol Pathol 1996;15:131-6. 154 Payne S, Kernohan NM, Walker F. Proliferation in the normal cervix and in preinvasive cervical lesions. $7 \mathrm{Clin}$ Pathol 1996;49:667-71.

155 Hall PA, Levison DA. Assessment of cell proliferation. $\mathcal{F}$ Clin Pathol 1990;43:184-92.

56 van de Schepop HAM, de Jong JS, van Diest PJ, et al. Apoptosis counting in breast cancer: a methodological study. F Clin Pathol Mol Pathol 1996;49:M214-17.

\section{Fournal of Clinical Pathology - http://www.jclinpath.com}

Visitors to the world wide web can now access the fournal of Clinical Pathology either through the BMJ Publishing Group's home page (http://www.bmjpg.com) or directly by using its individual URL (http://www.jclinpath.com). There they will find the following:

- Current contents list for the journal

- Contents lists of previous issues

- Members of the editorial board

- Information for subscribers

- Instructions for authors

- Details of reprint services.

A hotlink gives access to:

- BMJ Publishing Group home page

- British Medical Association web site

- Online books catalogue

- BMJ Publishing Group books.

The web site is at a preliminary stage and there are plans to develop it into a more sophisticated site. Suggestions from visitors about features they would like to see are welcomed. They can be left via the opening page of the BMJ Publishing Group site or, alternatively, via the journal page, through "about this site". 